This is the author's version of a work that was accepted for publication by Elsevier. Changes resulting from the publishing process, such as peer review, editing, corrections, structural formatting, and other quality control mechanisms may not be reflected in this document. Changes may have been made to this work since it was submitted for publication. A definitive version was subsequently published by Elsevier. 


\title{
Enhancing simultaneous response and amplification of biosensor in microbial fuel cell-based upflow anaerobic sludge bed reactor supplemented with zero-valent iron
}

\author{
Hui Jia ${ }^{\mathrm{a}, \mathrm{b}, *}$, Guang Yang ${ }^{\mathrm{a}, \mathrm{b}}$, Huu-Hao Ngo ${ }^{\mathrm{c}}$, Wenshan Guo ${ }^{\mathrm{c}}$, Hongwei Zhang a,b, \\ Fei Gao ${ }^{\mathrm{a}, \mathrm{d}}$, Jie Wang ${ }^{\mathrm{a}, \mathrm{b}, *}$ \\ ${ }^{a}$ State Key Laboratory of Separation Membranes and Membrane Process, Tianjin Polytechnic University, \\ Tianjin 300387, China \\ ${ }^{b}$ School of Environmental and Chemical Engineering, Tianjin Polytechnic University, Tianjin 300387, \\ China \\ ${ }^{c}$ Centre for Technology in Water and Wastewater, School of Civil and Environmental Engineering, \\ University of Technology Sydney, Sydney, NSW 2007, Australia \\ ${ }^{d}$ School of Environmental Science and Engineering, Tianjin University, Tianjin 300387, China \\ * Corresponding authors. E-mail addresses: wangjie@tjpu.edu.cn (H. Jia).
}

\begin{abstract}
The development of a convenient and sensitive sensor such as a microbial fuel cell (MFC) to monitor the operation of upflow anaerobic sludge blanket (UASB) is indispensable. However, the biosensor's properties were affected due to excessive acidification and suffocation of the electron transport. In this study, zero-valent iron (ZVI) was applied to restrain excessive acidification and improve the sensing performance. According to the results, the response rate of electrical signal accumulated with the addition of ZVI compared to the control reactor. As well as the electrical signal amplified and the subsidence rate maximum reached $0.059 \mathrm{~V} / \mathrm{h}$ with $30 \mathrm{mg} / \mathrm{L} \mathrm{ZVI}$ added that $883 \%$ higher than the control one during the stage (COD concentration $500 \mathrm{mg} / \mathrm{L}-$ $1000 \mathrm{mg} / \mathrm{L})$. With the electrochemical analysis, the internal resistance of ZVI-UASB-MFC decreased and redox activity promoted effectively with ZVI added. During the overloading phase, the fractional content of butyric acid changed from $53 \%$ to $31 \%$, while that of acetic acid rose from $18 \%$ to $39 \%$ after $30 \mathrm{mg} / \mathrm{L}$ ZVI addition. These results indicated that adding ZVI to the digestion could retard excessive acidification by promoting butyric acid conversion and accumulating direct interspecies electron transfer simultaneous for enhancing the biosensor's performance. According to the $\mathrm{Fe}^{2+}$ and $\mathrm{Fe}^{3+}$ of effluent were $2.25 \mathrm{mg} / \mathrm{L}$ and $0.39 \mathrm{mg} / \mathrm{L}$ with $50 \mathrm{mg} / \mathrm{L}$ ZVI addition, moderate amount of ZVI was effective for system and safety to the environment. It might helpfully provide a promising way to enhance biosensing.
\end{abstract}

Keywords: UASB-MFC; Zero-valent iron; Biosensor; Response; Amplification

\section{Introduction}

Currently, microbial fuel cell (MFC) devices that use bacteria as catalysts to oxidize organic or inorganic matter and generate current, are attracting increasing attention because they directly convert chemical energy into electricity in more than one step [1-3]. Due to the limitation of the theoretical electrogenesis voltage of the MFC and resultant possible losses, the maximum open circuit voltage of MFC is typically less than $0.8 \mathrm{~V}$ [4]. Even in the latest stacking MFCs in series can improve the voltage output [5]. However, the advantage gained by increasing the number of 
series-stacked MFCs may be offset by the concomitant electrical energy loss [6]. The MFCs inferior ability to generate power seriously restricts their application. Thus, utilized MFC as a sensor for pollutant detecting and in situ process monitoring is the potential application. Compared to other existing sensors, the MFC biosensor worked as a small bioreactor with characteristics of high sensitivity and long stability. For these reasons the MFC biosensor has received more attention and been used for Biochemical Oxygen Demand (BOD) [7], Dissolved Oxygen (DO) [8], toxicity [9], and Volatile Fatty Acid (VFA) sensing [10], etc.

Up-flow anaerobic sludge blanket (UASB) is an efficient biological approach for treating organic wastewater. However, the lack of reliable dynamic information and robust online sensors is one of the system's major problems. To achieve a more efficient and stable operation, the UASBMFC biosensor has been investigated for real-time monitoring of the UASB process through the electrical signal converted by MFC in a recent study, specifically in an easy operating format [11]. Biodegradable organic matter directly converted to electricity via MFC, and MFC itself is an integration of signal generator and transducer, which reduces the costs associated with external transducers. A major disadvantage of the biosensor is its reliance on biofilm for mediator-less electron transportation. Once acidification appears with microorganisms' inactivation, this causes the electron transmission rate slow down and biosensor become insensitive. To improve the properties of the UASB-MFC biosensor, new methods that vastly improve the electron transport rate from the biofilm covering an anode to the cathode and inhibiting acidification are much needed.

Zero-valent iron (ZVI) is an economic, efficient, and environment friendly reductive material that has been used widely in wastewater treatment and hazardous substance stabilization [12]. In anaerobic digestion, ZVI can provide electrons due to its low oxidation-reduction potential (ORP) $(\mathrm{E} 0=-440 \mathrm{mV})$ and serve as an acid buffer, which are crucial abilities that help maintain a stable and favorable state for methanogenic archaea, denitrifying bacteria, and sulfate reducing bacteria [13]. The most recognized mechanism of ZVI bio-availability is linked to the corrosion-induced $\mathrm{H} 2$, which can be utilized to reduce $\mathrm{CO} 2$ to methane by hydrogenotrophic methanogens [14]. The ZVI corrosion process in water releases Fe2+ irons, which contains a series of oxydrolysis and finally generates many types of hydrous ferric oxides. Since then, researchers have focused on utilizing ZVI (including nanoscale zero-valent iron (nZVI)) to treat pollution in the last decades which including dyes [15,16], nitrate [17,18], phenol [19,20], heavy metals [21,22], arsenic $[23,24]$, nitroaromatic compounds [25,26], chlorinated organic compounds [27,28], and aliphatic compounds $[29,30]$.

The combination of ZVI and anaerobic reactor has been investigated to facilitate the degradation of pollutants and been successfully applied to treat dairy wastewater [31]. One study confirmed that ZVI could significantly promote the diversity of microbial strains responsible for high efficiency in sludge [32]. Kaan Yetilmezsoy et al. [33] investigated the Fe-electrocoagulation technique for decolorization and chemical oxygen demand reduction of anaerobically pretreated poultry manure wastewater, about $90 \%$ COD and $92 \%$ of residual color be effectively removed. Cheng et al. [34] studied the pretreatment of concentrated wastewater from triazine manufactured by coagulation, electrolysis and internal microelectrolysis using iron chips. Wu et al. [12] observed that the moderate addition of ZVI can promote COD removal and methane production 
of the anaerobic system treated using swine wastewater. Liu et al. [35] reported that using a mathematical model, ZVI simultaneously enhances methane production and sulfate reduction in anaerobic granular sludge reactor.

Although many studies have documented that ZVI enhanced anaerobic digestion of various wastewaters, their effect on the MFC based biosensor has not been investigated. Considering its reductive properties, the main interest in applying ZVI in an anaerobic digestionbioelectrochemical field using wastewater or sludge as substrate was to create an enhanced anaerobic environment. It may help improve the performance of an anaerobic reactor. In this context, a marriage of the UASB-MFC and ZVI technologies would potentially provide an efficient way of utilizing the iron released by ZVI which could transfer electrons to an electrode for improving biosensor properties. The objective of this research was to investigate the acceleration effects of ZVI on the biosensor's signal response at different organic loading rates (OLR) and explore the mechanism of electron transport process variation when ZVI is added. The evolution of VFA in acidified reactors as the response to ZVI addition was investigated to explore the process of the positive inhibition effect of ZVI.

\section{Materials and methods}

\subsection{Experimental setup}

One kind of laboratory-scale microbial fuel cell-based up-flow anaerobic sludge blanket was set up (Fig. S1). The UASB-MFC reactor comprised a plexiglass cylinder consisting of an anode and cathode in which the UASB reactor worked as an anode chamber with a volume of $2.56 \mathrm{~L}$ (internal diameter of $6 \mathrm{~cm}$ and height of $50 \mathrm{~cm}$ ). The structure of the MFC was a single chamber without a proton exchange membrane (PEM) as described in a previous study [11]. The electrode was submerged in the UASB reactor and the anode electrode was made of carbon felt, with an apparent surface area of $50 \mathrm{~cm} 2$ and thickness of $5 \mathrm{~mm}$ (Beijing Fengxiang Co., Ltd., China). The air-cathode electrode was made of carbon cloth, with an apparent surface area of $50 \mathrm{~cm}^{2}$ and thickness of $1.5 \mathrm{~mm}$ (HCP330 N, Shanghai Hesen Co., Ltd., China). The anode electrode was previously washed in $1 \mathrm{M} \mathrm{HCl}$ and $1 \mathrm{M} \mathrm{NaOH}$ to remove possible metal and organic contamination. The cathode electrode via the pretreatment is according to previous research by Liu et al. [36]. The UASB-MFC was operated by feeding the wastewater through the bottom of the UASB using a peristaltic pump (BT100-2J, Baoding Longer Precision Pump Co., Ltd., China). Electrodes were connected to the data logging equipment via copper wires and titanium sheet with stainless steel crocodile clips under 0-9999 $\Omega$ controlled by a resistance box. $\mathrm{Ag} / \mathrm{AgCl}$ electrode $\left(3 \mathrm{M} \mathrm{KCl}, \mathrm{AgCl}\right.$ saturated, $0.210 \mathrm{~V}$ versus standard hydrogen electrode, $25{ }^{\circ} \mathrm{C}$, Shanghai Leici Co., Ltd., China) was set in the flange of the reactor as a reference electrode for measuring electrode potential, and its distance from anode and cathode was $2 \mathrm{~cm}$ and $2 \mathrm{~cm}$, respectively. A flow meter (LMF-1, Changchun Lvqingqi Co., Ltd., China) was connected to the gas outlet of the UASB. The system's operation temperature was thermostatically controlled at 26 $\pm 2{ }^{\circ} \mathrm{C}$.

Five reactors were used in the experiments to study the changes in electrochemical characteristics caused by ZVI in microbial fuel cell-based up-flow anaerobic sludge blanket systems. One 
reactor (R1) was supplemented without ZVI solution which served as the control reactor, whereas different concentrations of ZVI solution were supplied to the other four reactors (ZVI solution concentrations were $5 \mathrm{mg} / \mathrm{L}, 20 \mathrm{mg} / \mathrm{L}, 30 \mathrm{mg} / \mathrm{L}, 50 \mathrm{mg} / \mathrm{L}$ referred to as $\mathrm{R} 2, \mathrm{R} 3, \mathrm{R} 4, \mathrm{R} 5$, respectively).

\subsection{Reactor operating conditions}

The anaerobic active sludge was obtained from a secondary sedimentation tank treating municipal wastewater in Jizhuangzhi Wastewater Treatment Plant (Tianjin, China). An $850 \mathrm{ml}$ bacteria suspension was injected as inoculums into the UASB reactor in the laboratory and fed with a synthetic medium. It consisted of glucose as the carbon and energy source which facilitated biomass growth, urea and $\mathrm{KH}_{2} \mathrm{PO}_{4}$ as nitrogen and phosphorous sources, with a $\mathrm{C} / \mathrm{N} / \mathrm{P}$ ratio of 350/5/1 and $\mathrm{NaHCO}_{3}$ as $\mathrm{pH}$ buffer solution. Additionally, necessary trace metal elements were added to the influent to ensure that the environment was suitable for growing bacteria [37]. The medium composition was as follows (per liter): $\mathrm{Al}_{2}\left(\mathrm{SO}_{4}\right)_{3} \cdot 18 \mathrm{H}_{2} \mathrm{O}, 0.1 \mathrm{mg} ; \mathrm{MgSO}_{4} \cdot 7 \mathrm{H}_{2} \mathrm{O}$, $3 \mathrm{mg} ; \mathrm{FeSO}_{4} \cdot 7 \mathrm{H}_{2} \mathrm{O}, 3.5 \mathrm{mg} ; \mathrm{CaCl}_{2} \cdot 6 \mathrm{H}_{2} \mathrm{O}, 0.3 \mathrm{mg} ; \mathrm{ZnSO}_{4} \cdot 7 \mathrm{H}_{2} \mathrm{O}, 0.1 \mathrm{mg} ; \mathrm{CuCl}_{2} \cdot 2 \mathrm{H}_{2} \mathrm{O}, 0.2 \mathrm{mg}$; $\mathrm{MnSO}_{4} \cdot \mathrm{H}_{2} \mathrm{O}, 0.5 \mathrm{mg}$ as previously described [38]. During the test, the mixed liquor suspended solids (MLSS) concentration of the anode compartment was $8400 \mathrm{mg} / \mathrm{L}$ at set-up. Before conducting the batch experiments, the culture anaerobic sludge was washed with $\mathrm{N}_{2}$-sparged deionized water and stored under nitrogen gas for $24 \mathrm{~h}$ before using it in order to avoid the interference of the residual substrate.

The ZVI powder (purity $>98 \%, 400$ mesh, Tianjin Yingdaxigui chemical reagent factory., China) must be acid-washed before use in order to remove the surface oxides or other impurities. Prior to use, the ZVI powder was mixed with a $10 \%$ hydrochloric acid solution for $2 \mathrm{~min}$, then rinsed with $\mathrm{N}_{2}$-sparged deionized water, and finally dried under $\mathrm{N}_{2}$ gas. To facilitate the distribution of the ZVI powder throughout the sludge blanket, a stirrer was employed in the influent tank at regular intervals.

\subsection{Analytical methods}

The cell voltage (V) and potential (V) in the MFC circuit were monitored at 15 min intervals using an online multimeter with a data acquisition system (Agilent34972A, Agilent Tech Co., Ltd., USA). The anode potential was monitored with an $\mathrm{Ag} / \mathrm{AgCl}$ reference electrode. The precise $\mathrm{pH}$ meter (PHG-210, BohaiZhiyuan Tech Co., Ltd., China) was submerged in the UASB and measured the $\mathrm{pH}$ of solution in the nearby MFC. Conductivity was measured using a conductivity meter (DDS-307A, Shanghai Leici Co., Ltd., China). The concentration of COD in the effluent from the integrated system was measured according to the Standard Method [39].

Electrochemical tests were conducted using an electrochemical workstation (CHI660E, Chenhua Instruments Co., Ltd., Shanghai, China) and the electrochemical property of the electrodes was characterized by cyclic voltammetry $(\mathrm{CV})$. A conventional three-electrode system was employed with the cathode as the working electrode, the anode as the counter electrode, and an $\mathrm{Ag} / \mathrm{AgCl}$ reference electrode. The potentials between the working and reference electrodes were shifted from $-0.6 \mathrm{~V}$ to $0.6 \mathrm{~V}$ at a rate of $0.001 \mathrm{~V} / \mathrm{s}$ while monitoring the current response. The polarization curve of MFC was obtained by varying the external resistance from $10 \Omega$ to $9999 \Omega$ 
when the voltage was relatively stable. The Coulombic efficiency $(\mathrm{CE})$, defined as the fraction of electrons recovered as current versus that in the starting organic matter, at the steady state was calculated with Formula (1):

$$
\mathrm{CE}=\mathrm{C}_{\mathrm{p}} / \mathrm{C}_{\mathrm{t}} * 100 \%
$$

where $C_{p}$ is the total coulombs calculated by integrating the current over time, and $C_{t}$ is the theoretical amount of coulombs available based on the COD removed in the MFC.

Determining the dissolved Fe( II ) and Fe(III) was done using the Ferrozine method [40]. Absorbance of the Fe( II)-Ferrozine complex and Fe(III)-Ferrozine complex were measured at $562 \mathrm{~nm}$ on a UV spectrophotometer (Cary 60 UV-Vis, Agilent Tech Co., Ltd., USA).

The concentration and composition of VFAs were analyzed by a gas chromatograph (GC2018PFsc, SHIMADZU Tech Co., Ltd., Japan) with filtrate extracted from the sampled sludge and the filter liquor was obtained by filtration through a $0.45 \mu \mathrm{m}$ mixed cellulose ester membrane after centrifugation at $12,000 \mathrm{rpm}$ for $5 \mathrm{~min}$ priority. The $\mathrm{GC}$ was equipped with a flame ionization detector (FID) and a Nukol free fatty acid phase (FFAP) column (30 $\mathrm{m} \times 0.32 \mathrm{~mm}$ ). The GC column was initially held $80^{\circ} \mathrm{C}$ for $3 \mathrm{~min}$, increased by $15^{\circ} \mathrm{C} / \mathrm{min}$ to the final temperature of $210^{\circ} \mathrm{C}$, and then maintained at this temperature for $2 \mathrm{~min}$. The injection port and detector temperatures were both $230{ }^{\circ} \mathrm{C}$. Nitrogen gas saturated with formic acid was the carrier gas at $30 \mathrm{ml} \mathrm{min}^{-1}$. All the samples were acidified with $3 \% \mathrm{H}_{3} \mathrm{PO}_{4}$ before measurement and the injection volume was $1 \mu \mathrm{l}$. The total VFAs concentrations were calculated as a sum of the individual VFA concentrations.

Gas component was analyzed by a gas chromatograph (SP-7820, Lunan RuiHong Tech Co., Ltd., China) equipped with a thermal conductivity detector (TCD) and a $3 \mathrm{~m}$ stainless column. The temperatures of the injection, column and detector were $100{ }^{\circ} \mathrm{C}, 80^{\circ} \mathrm{C}$ and $100{ }^{\circ} \mathrm{C}$, respectively. Nitrogen was used as the carrier gas at a flow rate of $30 \mathrm{~mL} / \mathrm{min}$.

\section{Results and discussion}

\subsection{ZVI enhanced the signal amplification of the MFC biosensor}

During the start-up period, the anode compartment was inoculated with the influent in a continuous feed mode. A quintuplicate of MFC biosensors were operated under external load conditions from the beginning. As the reactors started up successfully, the systems all changed external resistance to $1000 \Omega$ and hydraulic retention time (HRT) to $12 \mathrm{~h}$. The signal response time characterized by $\mathrm{pH}$ was retarded due to the UASB having a buffering capacity for acid environment as documented in previous experiments. In view of the effect of $\mathrm{pH}$ on biosensor performance, an initial $\mathrm{pH} 6.8$ was used firstly in this study. Based on the reductive property, microelectrolysis and ion coagulation of the ZVI, the performance of the anaerobic reactor was enhanced by creating strengthening anaerobic environment. So the ZVI technology was applied to UASB-MFC biosensor. To make clear the role of ZVI in the biosensor in response to the rising substrate concentration, the five reactors were fed with the synthesis wastewater, in which COD concentration rose from $500 \mathrm{mg} / \mathrm{L}$ to $6000 \mathrm{mg} / \mathrm{L}$ in five levels and the OLR correspond 
$0.36 \mathrm{gCOD} / \mathrm{gMLSS} \mathrm{d}$ to $4.32 \mathrm{gCOD} / \mathrm{gMLSS} \mathrm{d}$. Fig. 1 shows the results indicated that the response time point occurring in different influent concentrations was affected by the addition of ZVI. Furthermore the electric signal changed in concentration of transform had been amplified partially simultaneously.

Fig. 1(a)-(d) presents the phenomenon that the electric signal amplified during the period of COD concentration varied from $500 \mathrm{mg} / \mathrm{L}$ to $1000 \mathrm{mg} / \mathrm{L}, 2000 \mathrm{mg} / \mathrm{L}, 4000 \mathrm{mg} / \mathrm{L}$, finally to $6000 \mathrm{mg} / \mathrm{L}$ step by step, respectively. Each substrate was injected into the system initially until the voltage reached a steady state and then switched to another concentration. The voltage increased gradually and steadily over $60 \mathrm{~h}$, and then increased to $1000 \mathrm{mg} / \mathrm{L}$ in Fig. 1(a). The voltage of different reactors in the steady state with COD $500 \mathrm{mg} / 1$ increased to $0.495 \mathrm{~V}$ from $0.436 \mathrm{~V}$ with the initial amount of added ZVI, but higher doses would make the ZVI-facilitated effect weaker. The voltage generated by R4 was higher than the other reactors and then increased COD to $1000 \mathrm{mg} / \mathrm{L}$. As previously analyzed, the electrical signal response was slightly delayed due to the changes in the solution concentration being lower than the threshold value of the changed sensor. On the other hand, the effects wielded by the ZVI were felt not only on the response time but also on the degree of the quantitative response metrics.
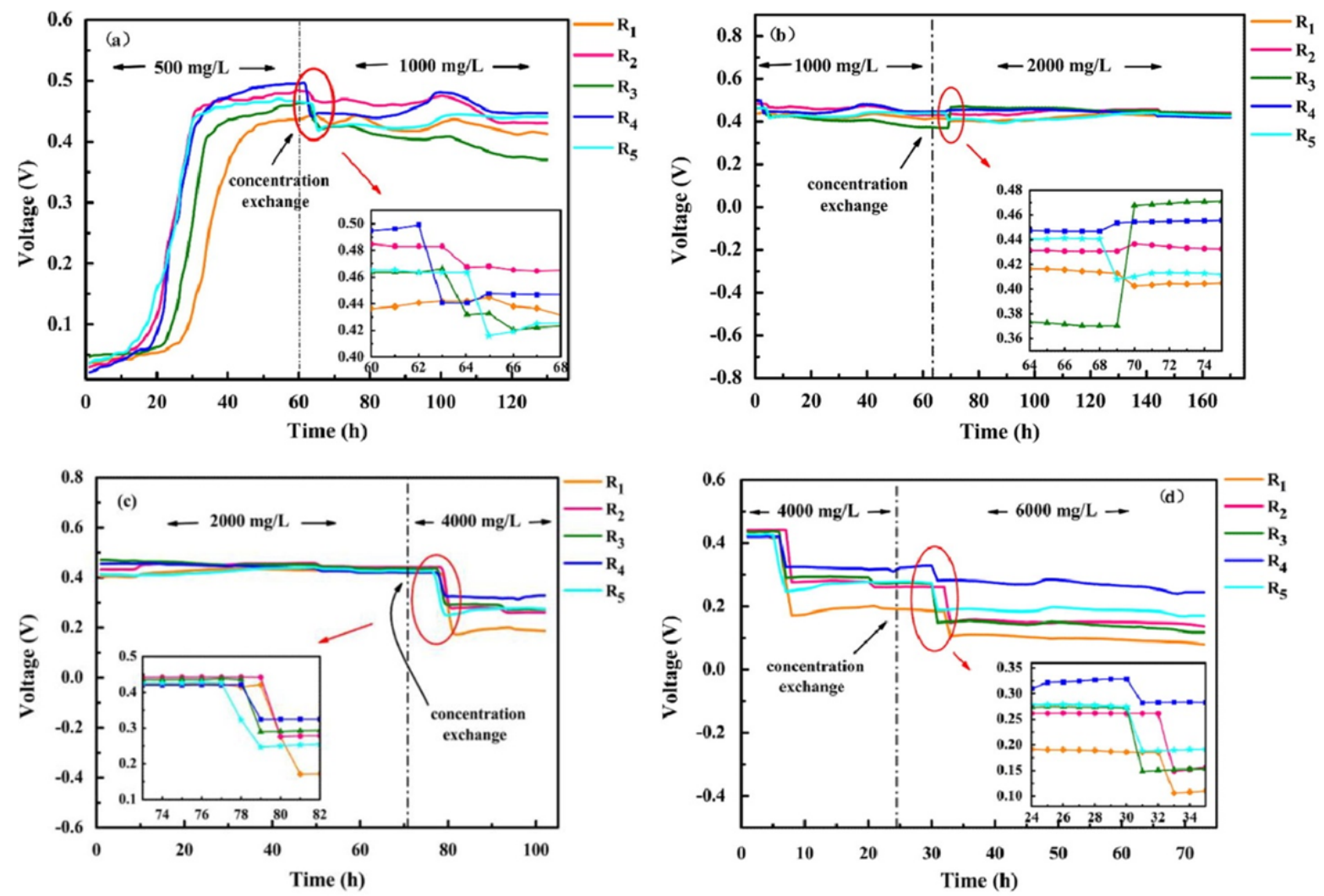

Fig. 1. Evolution of voltage generation of the MFC biosensor at various amounts ZVI. (a) COD concentration up to $1000 \mathrm{mg} / \mathrm{L}$ from $500 \mathrm{mg} / \mathrm{L}$; (b) COD concentration up to $2000 \mathrm{mg} / \mathrm{L}$ from $1000 \mathrm{mg} / \mathrm{L}$; (c) COD concentration up to $4000 \mathrm{mg} / \mathrm{L}$ from $2000 \mathrm{mg} / \mathrm{L}$; (d) COD concentration up to $6000 \mathrm{mg} / \mathrm{L}$ from $4000 \mathrm{mg} / \mathrm{L}$

As can be seen in Fig. 1(a) and (b), the electrical signal in R1 runs smoothly when the substrate concentration increased from $500 \mathrm{mg} / \mathrm{L}$ to $2000 \mathrm{mg} / \mathrm{L}$ and the subsidence rates were lower than 
the reactors with added ZVI. Here the subsidence rates in R1 to R5 were $0.006 \mathrm{~V} / \mathrm{h}, 0.014 \mathrm{~V} / \mathrm{h}$, $0.035 \mathrm{~V} / \mathrm{h}, 0.059 \mathrm{~V} / \mathrm{h}, 0.048 \mathrm{~V} / \mathrm{h}$ in stage $1(500-1000 \mathrm{mg} / \mathrm{L})$, respectively, which the subsidence rate increased by $133 \%, 483 \%, 883 \%, 700 \%$ that $\mathrm{R} 1$ compared with other reactors added different amounts of ZVI. The voltages all stabilized at nearly $0.42 \mathrm{~V}$ with substrate to $2000 \mathrm{mg} / \mathrm{L}$ and there was no variation except for an obvious significant acceleration occurring in R3. In this particular scenario the rate was $0.097 \mathrm{~V} / \mathrm{h}$ during the process where stage 1 transformed to stage2 $(1000-2000 \mathrm{mg} / \mathrm{L})$. By adding ZVI, the quantitative response metric was amplified significantly, and the response rate varied based on the ZVI dose. This was mainly due to ZVI could be released from $\mathrm{Fe}^{0}$ to $\mathrm{Fe}^{2+}\left(\mathrm{Fe}^{0}+2 \mathrm{H}^{+}=\mathrm{Fe}^{2+}+\mathrm{H}_{2}\right)$ and it changed the iron's strength inordinately and compressed electric double layer of sludge effectively as well. However, it was inaccuracy that the bigger the ZVI dose the better sensing property. The inhibition was caused by high ZVI concentration due to a corrosion-induced increase in $\mathrm{pH}$ beyond the optimum range of the biologically sensitive material for maximum activity as the biosensor's operating conditions were rigorous [41].

During the COD concentration of $2000 \mathrm{mg} / \mathrm{L}-6000 \mathrm{mg} / \mathrm{L}$ (Fig. 1c and d), the voltages of every sensors all decreased significantly in unit time and the subsidence rates of R1 were $0.124 \mathrm{~V} / \mathrm{h}$ and $0.079 \mathrm{~V} / \mathrm{h}$. These were lower than R2 $(0.165 \mathrm{~V} / \mathrm{h}$ and $0.112 \mathrm{~V} / \mathrm{h})$ and $\mathrm{R} 3(0.146 \mathrm{~V} / \mathrm{h}$ and $0.125 \mathrm{~V} / \mathrm{h})$ in stage3 $(2000-4000 \mathrm{mg} / \mathrm{L})$ and stage4 $(4000-6000 \mathrm{mg} / \mathrm{L})$, respectively. However, the quantitative response metrics in R4 $(0.097 \mathrm{~V} / \mathrm{h}$ and $0.047 \mathrm{~V} / \mathrm{h})$ and $\mathrm{R} 5(0.104 \mathrm{~V} / \mathrm{h}$ and $0.086 \mathrm{~V} / \mathrm{h}$ ) were relatively lower. It has been suggested that ZVI can help buffer the acidity to maintain a near neutral $\mathrm{pH}$ in the reactor, therefore improving exoelectrogen and enabling the UASB reactor to better respond to changes in wastewater quality. Although the $\mathrm{pH}$ of the ZVIbiosensor was less than ideal, it belonged in the growth range and will collapse once beyond that range.

See things from another side, the electrical signal amplification is the phenomenon that the concentration of target material generated by the signal transduction process is much higher than the level which the input signal could be. The input signal was gradually exaggerated through the signal transduction cascade, and generated the enzyme or effector molecule working on the target material. Thus the electrical signal was linearly correlated with the organic concentration and the amplification process was affected by the organic matter degradation rate.

Fig. S2 highlights the differences in COD digestion rate versus time in days. During the moderate loading phase (COD loads were $0.36-1.44 \mathrm{gCOD} / \mathrm{gMLSS} \mathrm{d}$ ), the COD digestion rates in all reactors were above $50 \%$ and obtained excellent effect in the best COD load was $0.72 \mathrm{gCOD} / \mathrm{gMLSS} \mathrm{d}$. The environment in the system proved to be suitable for the growth of germ and improved the activity of microorganisms. It also ensured that the organics degraded completely and generated methane simultaneously. In contrast, the digestion rate decreased significantly when the COD load rose to $4.32 \mathrm{gCOD} / \mathrm{gMLSS} \mathrm{d}$ which be in overloading phase (COD loads were 2.88-4.32 gCOD/gMLSS d). Taking everything into consideration, the digestion rates of reactors which were supplied with ZVI were higher than those observed in the control test. The maximum digestion rate obtained was ZVI of $30 \mathrm{mg} / \mathrm{L}$, which proved to be a little faster than that observed at the ZVI of $50 \mathrm{mg} / \mathrm{L}$, suggesting that the redundant ZVI showed no more facilitating effect. The ZVI-facilitated COD digestion process was achieved mainly 
through the way that ZVI worked as a slow release electron donor to promote the biodegradation of organics and directly reduce contaminants at its surface. The results were consistent with the phenomenon illustrated in Fig. 1.

\subsection{ZVI enhanced the response of MFC biosensor}

Fig. 2 shows that the variation in voltage and $\mathrm{pH}$ in different COD at various amounts of ZVI. The COD concentration changed from $500 \mathrm{mg} / \mathrm{L}$ to $1000 \mathrm{mg} / \mathrm{L}$ at the 20 th hour. The voltage and $\mathrm{pH}$ decreased after the concentrations changed $5 \mathrm{~h}$ and $10 \mathrm{~h}$, respectively. However, the voltage response time points of other biosensors with different amounts of added ZVI were $4 \mathrm{~h}, 3 \mathrm{~h}, 2 \mathrm{~h}$, $4 \mathrm{~h}$, respectively. It can thus be seen that ZVI accelerated the response rate of the electrical signal and shortened response time simultaneously. On the basis of an analysis of $\mathrm{pH}$ response, ZVI curtailed $\mathrm{pH}$ response time inconspicuously to $10 \mathrm{~h}, 9 \mathrm{~h}, 6 \mathrm{~h}, 8 \mathrm{~h}$, respectively.
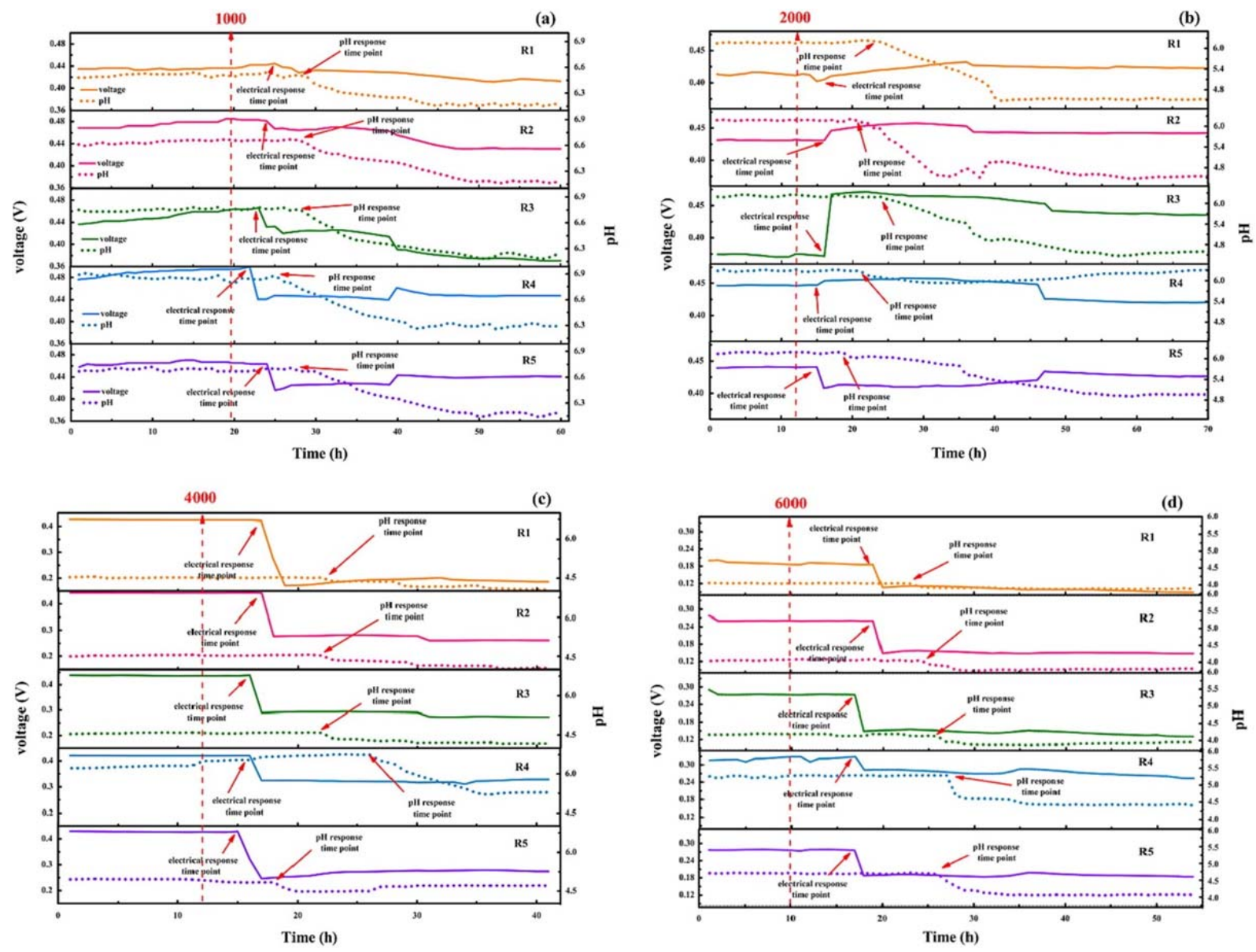

Fig. 2. The variation in voltage and $\mathrm{pH}$ in different $\mathrm{COD}$ concentrations at various amounts of ZVI. (a) the variation in COD concentration of $500 \mathrm{mg} / \mathrm{L}-1000 \mathrm{mg} / \mathrm{L}$; (b) the variation in COD concentration of $1000 \mathrm{mg} / \mathrm{L}-2000 \mathrm{mg} / \mathrm{L}$; (c) the variation in COD concentration of $2000 \mathrm{mg} / \mathrm{L}-$ $4000 \mathrm{mg} / \mathrm{L}$; (d) the variation in COD concentration of $4000 \mathrm{mg} / \mathrm{L}-6000 \mathrm{mg} / \mathrm{L}$

Fig. 2(b-d) shows some phenomena with different $\mathrm{pH}$ response to other artificial water concentration after the addition of ZVI. ZVI shortened electrical signal response time in both high concentration $(6000 \mathrm{mg} / \mathrm{L})$ and low concentration $(500 \mathrm{mg} / \mathrm{L})$, and meanwhile the response rate decreased when the organic loading rate increased oppositely. The fluctuation in $\mathrm{pH}$ appealed 
significantly with COD increased to $2000 \mathrm{mg} / \mathrm{L}$ except the $\mathrm{pH}$ of $\mathrm{R} 4$ maintained stability at 6.2. On the other hand, the degree of $\mathrm{pH}$ declined were different in which that R1-R3 fall off sharply,R4 maintained stabile and R5 dropped placidly, respectively. During the overloading phase, acidification occurred when COD increased to $4000 \mathrm{mg} / \mathrm{L}$ and $6000 \mathrm{mg} / \mathrm{L}$ and ZVI could delay the response of $\mathrm{pH}$ inversely. It indicated that the electrical signal and $\mathrm{pH}$ sensing occurred through different transmission channels and different kinds of microorganisms. In these contexts they functioned as two independent systems and ZVI buffered $\mathrm{pH}$. So that the range ability and sensitivity of $\mathrm{pH}$ brought down, and difficult judging operation status within $\mathrm{pH}$ variation during the overloading phase.

As shown in Fig. S3, the speed of the electrical signal's response increased and the response time shortened with the addition of ZVI under different OLR. Besides, the response time elongated when the OLR increased. This phenomenon was caused by the influence of ZVI or VFA. The impact of ZVI directly on the voltage response was evident when the operating conditions were invariable. In addition, the sensing time was suppressed significantly as the loading increased while the ZVI dosing quantity was in a fixed condition. This was mainly due to the VFA affect the sensing time as the primary reason, but ZVI weaken the influence of VFA on sensing time.

According to the above phenomena, the mechanism of ZVI affected sensing property was not fully identical with different operating conditions. In the moderate loading phase, the ORP and electron transfer of MFC were facilitated by ZVI. The processes of reaction and sensor capability were affected by ZVI through the VFA which changed during the overloading phase and provided an appropriate environment in which exoelectrogens and methanogens bacteria could grow. Thus the response of the biosensor was strengthened due to exoelectrogen microorganisms accelerating the electron transfer process. The impact of ZVI on VFA was studied by examining the variation of total VFA and proportion of VFA, which are discussed in the following sections.

\subsection{Effect of ZVI on excessive acidification inhibition in different $O L R$}

Under anaerobic conditions, organic matter was initially hydrolyzed and fermented into acetic acid and hydrogen, which could be further utilized through methanogenesis for methane production [42]. Every stage needed specific microorganisms play a role to maintain the ecological balance of the system. Including methanogens decided the anaerobic digestion process. However the substrate which methanogens could utilized was limited, and both the system acidified and biosensing inhibited after the methanogens metabolism was restrained. VFA used as the appropriate substrate could be easily degraded and provided a suitable environment for electrochemically active bacteria and methanogens to grow in. Rabaey et al. showed that electricity generated in an MFC resulted in large part from the production of mediators, or electron shuttles, by a microbial community consisting of primarily three bacteria: Alcaligenes faecalis, Enterococcus faecium, and Pseudomonas aeruginosa [43]. Therefore, the key point was focused on how to elevate the acetic acid production, and avoid the propionic acid and butyric acid which difficult to spontaneous transformation.

To explore the effects of ZVI on the proportion of VFA and anaerobic digestion during the moderate loading phase and overloading phase, respectively, the measurement was conducted in triplicate. Fig. 3 presents the total VFA produced in stable operating conditions at influent 
concentration ranging from $500-6000 \mathrm{mg} / \mathrm{L}$. The total VFA increased with an improvement in influent organic loading and the anaerobic digestion reaction was restrained when much organic matter could not be consumed and VFA has accumulated. Since the total VFA of each system all in a lower level of $70 \mathrm{mg} / \mathrm{L}$ under low-load, while the total VFA soared to $1400 \mathrm{mg} / \mathrm{L}$ within system acidified gradually. The total VFA varied with ZVI dosage in the same acidulated state. During the operating condition of COD was $6000 \mathrm{mg} / \mathrm{L}$, the total VFA declined from $1424 \mathrm{mg} / \mathrm{L}$ to $814 \mathrm{mg} / \mathrm{L}$ with the ZVI concentration increasing to $50 \mathrm{mg} / \mathrm{L}$. This was mainly due to its strong reductive property, and ZVI is expected to provide electrons for methanogenesis by producing water-derived $\mathrm{H}_{2}$ during corrosion: $\mathrm{Fe}^{0}+2 \mathrm{H}_{2} \mathrm{O} \rightarrow \mathrm{Fe}^{2+}+2 \mathrm{OH}^{-}+\mathrm{H}_{2}$ [44].

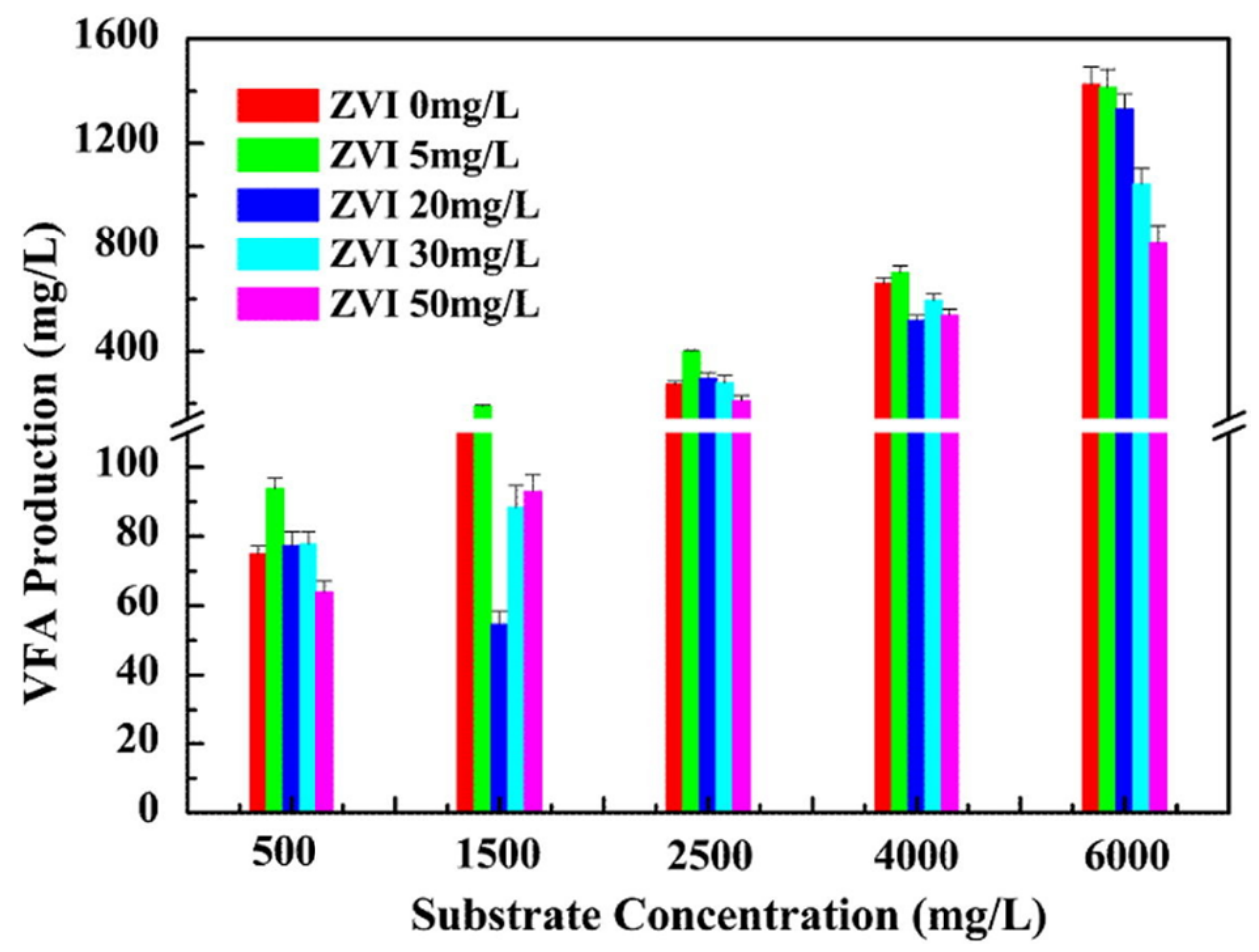

Fig. 3. Change in total VFA production at different COD concentrations with respect to different reactors

The biogas production at $0.72 \mathrm{gCOD} / \mathrm{gMLSS} \mathrm{d}$ was recorded in Fig. S4. The total biogas production and methane production increased with the ZVI dosage and higher than the control one. It indicated that ZVI enhanced the activity of methanogens and improved the methane production. The VFA was utilized by methanogens and declined gradually. Besides, the biogas production was limited significantly in acidification (Fig. S5). Due to ZVI could serve an electron donor for reducing $\mathrm{CO}_{2}$ into $\mathrm{CH}_{4}$ based on the reactions that $4 \mathrm{Fe}^{0}+\mathrm{CO}_{2}+8 \mathrm{H}^{+}=4 \mathrm{Fe}^{2+}+\mathrm{CH}_{4}+2 \mathrm{H}_{2} \mathrm{O}$ and $\mathrm{CO}_{2}+4 \mathrm{H}_{2}=\mathrm{CH}_{4}+2 \mathrm{H}_{2} \mathrm{O}$. Hydrogen ion was consumed and resulted in acid anesis. The production of biogas picked up although still lower than that at moderate loading rate. Therefore, ZVI control acid production positively could be reflected by the variation of biogas production. Combined with the biosensor response time of each system indicated that adding ZVI not only improved the efficiency of hydrolysis acidification, but also reinforced the effect of hydrolysis acidification. Feng et al. [45] found that ZVI promoted protein and cellulose decomposition in sludge and that the activities of several key enzymes related to hydrolysis and acidification increased. ZVI plays an important role in 
reducing the loading in the subsequent processes, and formatting the favorable forms of organic acids simultaneously.

Fig. 4 shows the individual VFA proportions in the anaerobic combined system at ZVI concentrations of $0,5,20,30$ and $50 \mathrm{mg} / \mathrm{L}$. This result indicated that acetic acid was given priority in reaching nearly $50 \%$ in the control reactor and ZVI-reactor during the moderate loading phase $(500-1500 \mathrm{mg} / \mathrm{L})$. ZVI had a slight effect on the composition of VFA. When the reactor was fed with a COD concentration of more than $4000 \mathrm{mg} / \mathrm{L}$, a significant variation in VFA composition was observed. Taking the COD concentration of $6000 \mathrm{mg} / \mathrm{L}$ for example, the VFAs consisted mainly of n-butyric acid (52\%) and acetic acid (18\%), but minor quantities of propionic acid (4\%) were generated with ZVI amounting to $0 \mathrm{mg} / \mathrm{L}$. Acetic acid increased gradually as n-butyric decreased, and propionic acid, n-valeric acid remained unchanged with added ZVI. When the ZVI concentration was $50 \mathrm{mg} / \mathrm{L}$, an obviously amplitude in variation was observed. The n-butyric acid decreased from $53 \%$ to $31 \%$ and meanwhile the acetic acid increased from $18 \%$ to $39 \%$. This indicated that acidogenesis in anaerobic digestion occurring during the acidification phase followed n-butyric type fermentation, in which the major metabolites were n-butyric acid, acetic acid and some propionic acid [31]. A large of NADH and $\mathrm{H}^{+}$were produced during acid-producing, and the acidification caused by the acid terminal products. The low $\mathrm{pH}$ brought about the negative feedback regulation. However, NADH and $\mathrm{H}^{+}$ and the acid terminal products reduced by butyric acid metabolism. Thus the catabolism process of carbohydrate operated normally.

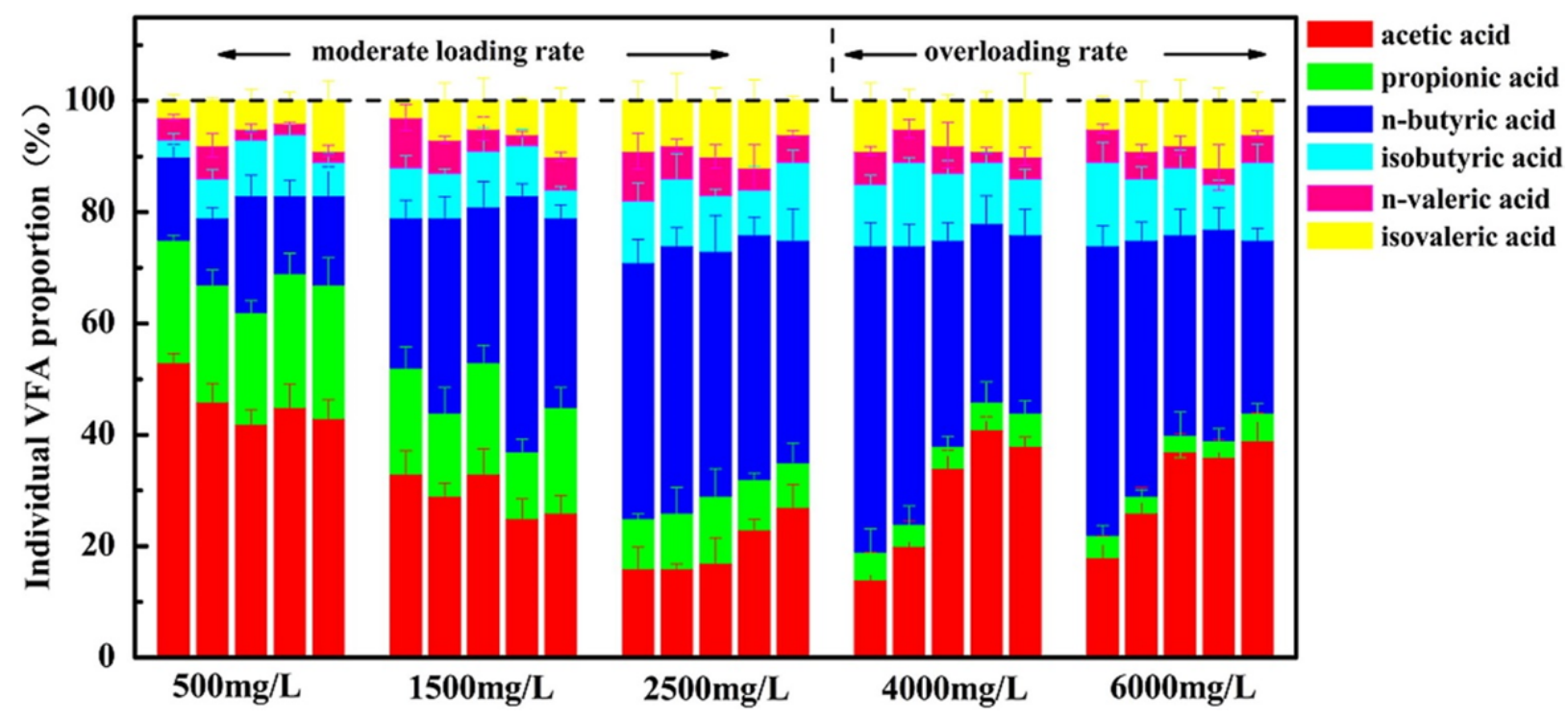

Fig. 4. Production profile of individual VFA produced at different ZVI concentrations with respect to different COD

After adding ZVI, the ratio of acetic acid increased, the propionic acid and butyric acid decreased conversely. Propionic acid and butyric acid could not be converted into acetic acid spontaneously with high hydrogen partial pressure and ORP, as stated by the following equations:

$$
\begin{aligned}
& \mathrm{CH}_{3} \mathrm{CH}_{2} \mathrm{COO}^{-}+3 \mathrm{H}_{2} \mathrm{O} \rightarrow \mathrm{CH}_{3} \mathrm{COO}^{-}+\mathrm{HCO}_{3}^{-}+\mathrm{H}^{+}+3 \mathrm{H}_{2} \\
& \Delta \mathrm{G}=+76.1(\mathrm{KJ} / \mathrm{mol})
\end{aligned}
$$


$\mathrm{CH}_{3} \mathrm{CH}_{2} \mathrm{CH}_{2} \mathrm{COO}^{-}+2 \mathrm{H}_{2} \mathrm{O} \rightarrow 2 \mathrm{CH}_{3} \mathrm{COO}^{-}+\mathrm{H}^{+}+2 \mathrm{H}_{2}$

$\Delta \mathrm{G}=+48.1(\mathrm{KJ} / \mathrm{mol})$

Normally, the butyric acid and propionic acid did not change during the process, and their concentrations remained stable due to a positive $\Delta \mathrm{G}$; this led to their fractional contents increasing relatively. After the addition of ZVI, the activities of acetoclastic and hydrogenotrophic methanogens increased, and $\mathrm{H}_{2}$ partial pressure and acetic acid concentration decreased. Consequently the acetic acid concentration and ORP decreased to a certain extent. $\Delta \mathrm{G}$ became negative and the acid which degradation-resistant such as butyric acid and propionic acid were able to be converted to acetic acid. As a result, the fractional content of acetic acid increased and butyric acid with propionic acid decreased conversely [46]. This suggests that ZVI positively inhibited excessive acidification and regulated the composition of individual VFA so that the system continued to operate steadily. However, the ferric toxicity and inhibition of microorganism activity occurred with excessive addition of ZVI. This was attributed to the corrosion reaction and deposition of ZVI in the system. In addition, ZVI acts as an electron donor that can reduce ORP and promote the electron transfer process. Therefore, an appropriate ZVI dosage did improve the biosensor's performance.

\subsection{The influence of ZVI on the electron transfer process in the biosensor under different phases of anaerobic digestion}

When the current passed through the electrode, the electrode's potential deviated from the phenomenon of balance potential. Fig. 5 illustrates the polarization curve of MFC biosensors with variant ZVI in the moderate loading phase $(0.72 \mathrm{gCOD} / \mathrm{gMLSS} \mathrm{d})$ and overloading phases (4.32 $\mathrm{gCOD} / \mathrm{gMLSS} \mathrm{d})$, respectively. An increase in power density occurred when at first the current density increased, followed by decrease in current density. The peak-shaped curve occurred mainly due to polarization of internal resistance. As shown in Fig. 5(a), the control delivered a maximum power density of $0.029 \mathrm{~W} / \mathrm{m}^{2}$ with a current density of $0.135 \mathrm{~A} / \mathrm{m}^{2}$ which were much lower than that with added ZVI. When $30 \mathrm{mg} / \mathrm{L}$ of ZVI was added to R4, the maximum power density reached $0.093 \mathrm{~W} / \mathrm{m}^{2}$ which is 3.2 times larger than $\mathrm{R} 1$. This was mainly due to the strong ionic strength solution enhancing the direct interspecies electron transfer on the anode surface and promoted reproduction and attachment of bacteria on this surface. However, during the overloading phase (Fig. 5(b)), the power densities were generally smaller than that in the moderate loading phase. The maximum power density of R1 to R5 declined to $0.002 \mathrm{~W} / \mathrm{m}^{2}$. $0.007 \mathrm{~W} / \mathrm{m}^{2}, 0.004 \mathrm{~W} / \mathrm{m}^{2}, 0.04 \mathrm{~W} / \mathrm{m}^{2}$, and $0.043 \mathrm{~W} / \mathrm{m}^{2}$, respectively.

The cathode exhibited the overpotential for the control reactor both in moderate loading phase and overloading phase, with the voltage decreasing sharply from the open circuit potential. Glucose with ZVI sustained a higher current density which maximum reached 3.5 times $(0.9$ versus $\left.0.26 \mathrm{~A} / \mathrm{m}^{2}\right)$ and 6 times $\left(0.42\right.$ versus $\left.0.07 \mathrm{~A} / \mathrm{m}^{2}\right)$ that measured for glucose-fed one in moderate loading phase and overloading phase, respectively. High current densities under high ZVI concentration meant that faster reaction rate and bacteria uptake of glucose with ZVI. It might accelerate the cathode oxygen reduction with proton and lead to the increase of $\mathrm{pH}$.

As can be seen in Table 1, the capability of MFCs with added ZVI was better than the control, in which the ORP in R1 was $-385 \pm 18 \mathrm{mV}$ vs SHE, and Coulomb efficiency was $3.4 \%$. 
Consequently, ZVI proved to be an efficient reductive material, effectively converting existing electrons in MFC into electrical energy. It also improved electronic recovery with less Coulomb being lost in the electrochemical system. The MFCs had lower ORP and the lowest was $-435 \pm 22 \mathrm{mV}$ vs SHE with $30 \mathrm{mg} / \mathrm{L}$ of ZVI added into the system. Meanwhile, it was provided favorable property of biosensor such as Coulomb efficiency, internal resistance, stabled $\mathrm{pH}$ and so on. From another perspective, ZVI via hydrolysis produced ferrous iron, enhanced the ionic strength of the solution and anodizing properties. The conductivity increased gradually with an increase in the dosage of ZVI which was higher than the control group. The $\mathrm{pH}$ level in these ZVI-UASB reactors was always well maintained and this was suitable for exoelectrogen growth. This could be explained by the ZVI counteracting the acidity due to the $\mathrm{Fe}^{2+} / \mathrm{Fe}^{0}\left(\mathrm{E}_{0}=-0.44 \mathrm{~V}\right)$ having lower ORP than $\mathrm{H}^{+} / \mathrm{H}_{2}\left(\mathrm{E}_{0}=0\right)$. On this account, combined with the signal response and amplification phenomenon of the former part indicated that ZVI promoted the direct interspecies electron transfer of MFC and this enhanced the biosensing function.
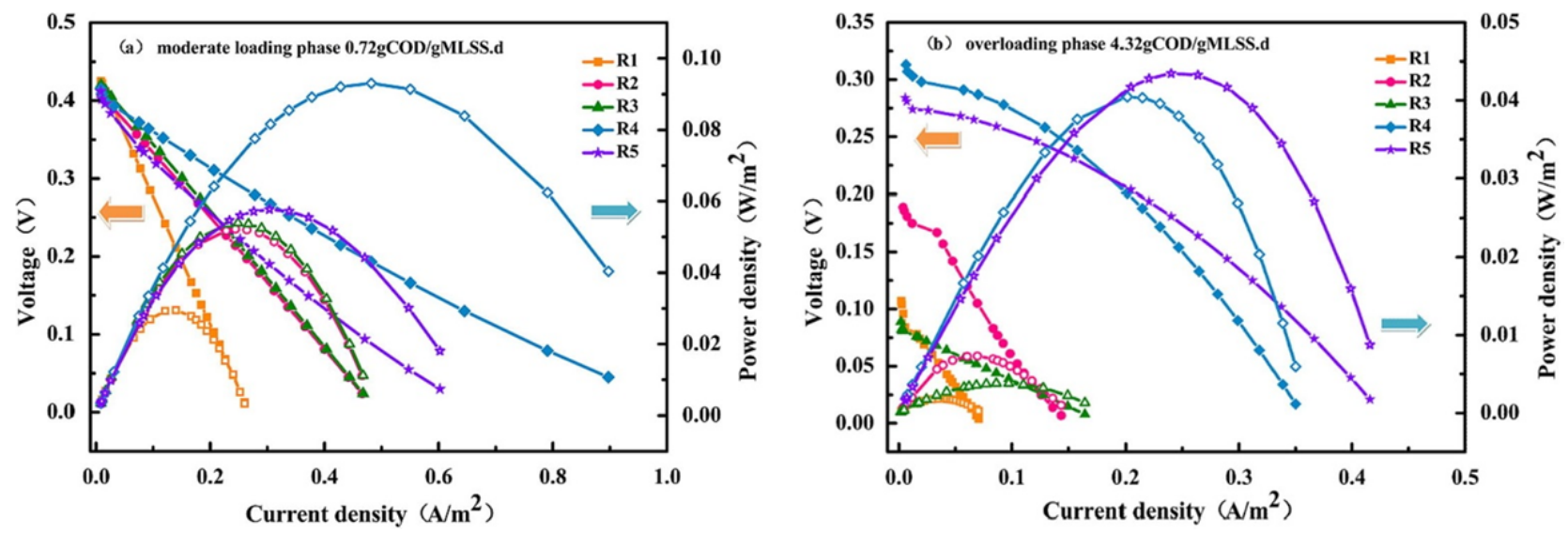

Fig. 5. Polarization curves and power curves of MFCs equipped with different ZVI during (a) moderate loading phase (0.72 gCOD/gMLSS d) and (b) overloading phase (4.32 gCOD/gMLSS d)

Table 1. Differences in MFC performance between each system with various amounts of added ZVI during OLR was $0.72 \mathrm{gCOD} / \mathrm{gMLSS}$ d.

\begin{tabular}{lllllc}
\hline $\mathbf{r}_{\text {ZVI }}(\mathbf{m g} / \mathbf{L})$ & $\begin{array}{c}\text { Coulomb efficiency } \\
(\mathbf{\%})\end{array}$ & $\begin{array}{c}\text { Internal resistance } \\
(\boldsymbol{\Omega})\end{array}$ & Conductivity $(\boldsymbol{\mu s} / \mathbf{c m})$ & $\begin{array}{c}\text { Final anode potential } \\
(\mathbf{m V} \text { vs SHE) }\end{array}$ & Final $\mathbf{~ p H}$ \\
\hline 0 & 3.4 & 267 & $0.162 \times 10^{3}$ & $-385 \pm 18$ & $6.52 \pm 0.32$ \\
5 & 3.7 & 168 & $0.277 \times 10^{3}$ & $-414 \pm 23$ & $6.42 \pm 0.21$ \\
20 & 4.5 & 175 & $0.326 \times 10^{3}$ & $-427 \pm 52$ & $6.78 \pm 0.25$ \\
30 & 6.2 & 76 & $0.472 \times 10^{3}$ & $-435 \pm 22$ & $6.96 \pm 0.13$ \\
50 & 5.4 & 112 & $0.558 \times 10^{3}$ & $-419 \pm 37$ & $6.83 \pm 0.19$ \\
\hline
\end{tabular}

Table 2 summarizes the electrochemical characteristics during OLR was $4.32 \mathrm{gCOD} / \mathrm{gMLSS}$ d. In this phase, the systems appeared acidification phenomenon seriously. Its impact on the electrochemical characteristics was very severe compared to the moderate loading phase. As a result of the Coulomb efficiency, internal resistance, anode potential and other aspects were all restrained with the concrete expression that the Coulomb declined from $3.4 \%$ to $1.4 \%$ in the moderate loading phase of the control group, and the internal resistance rose to $327 \Omega$ and $\mathrm{pH}$ tobogganed to 3.88, respectively. A rigorous growth environment ensured the problems arose easily. Using the longitudinal method as a contrast, the inhibition of electrochemical 
characteristics relieved and maximum extent compensated for the effects of acidification of biosensor properties due to the action of ZVI.

Table 2. Differences in MFC performance between each system with various amounts of added ZVI during OLR was $4.32 \mathrm{gCOD} / \mathrm{gMLSS} \mathrm{d}$

\begin{tabular}{llllll}
\hline $\mathbf{r}_{\mathbf{Z V I}}(\mathbf{m g} / \mathbf{L})$ & $\begin{array}{c}\text { Coulomb efficiency } \\
(\mathbf{\%})\end{array}$ & $\begin{array}{c}\text { Internal resistance } \\
(\boldsymbol{\Omega})\end{array}$ & Conductivity ( $\mathbf{\mu s} / \mathbf{c m})$ & $\begin{array}{c}\text { Final anode potential } \\
(\mathbf{m V} \text { vs SHE) }\end{array}$ & Final pH \\
\hline 0 & 1.4 & 327 & $0.18 \times 10^{3}$ & $-274 \pm 18$ & $3.88 \pm 0.32$ \\
5 & 1.7 & 285 & $0.32 \times 10^{3}$ & $-300 \pm 23$ & $3.81 \pm 0.21$ \\
20 & 2.5 & 193 & $0.384 \times 10^{3}$ & $-334 \pm 52$ & $3.95 \pm 0.25$ \\
30 & 4.2 & 91 & $0.507 \times 10^{3}$ & $-400 \pm 22$ & $4.43 \pm 0.13$ \\
50 & 3.4 & 130 & $0.642 \times 10^{3}$ & $-389 \pm 37$ & $4.08 \pm 0.19$ \\
\hline
\end{tabular}

To gain more insights into the effect of ZVI and VFA on electron transfer, CVs were obtained for all anodes under both moderate loading phase (0.72 gCOD/gMLSS d) and overloading phase (4.32 gCOD/gMLSS d) after operation stabled. The oxidation and reduction peaks observed with different ZVI addition were distinct in sharp (Fig. 6a). Only two reduction peaks were obtained at $-0.15 \mathrm{~V}$ and $0.3 \mathrm{~V}$, respectively and no oxidation peak was found for R1. When $5 \mathrm{mg} / \mathrm{L} \mathrm{ZVI}$ was added to UASB-MFC biosensor, a small oxidation peak and reduction peak were located at $-0.17 \mathrm{~V}$ and $-0.06 \mathrm{~V}$, corresponding peaks current were $0.2 \mathrm{~mA}$ and $-1.07 \mathrm{~mA}$, respectively. With ZVI increased each current peak increased, indicating that these peaks resulted from organic degraded through ZVI enhanced the electrochemical activity of bacteria at the anode. As shown in Fig. 6(b), no redox couples were detected in the cyclic voltammetry curve under overloading phase. CVs for the anodes were nearly identical at different ZVI concentration. While no other obvious redox peak were obtained and there was a slight broadening of the curves with increased ZVI concentration. The activity of electrogenesis microorganism was inhibited in the long-term acidification condition and the electron transport rate was restricted otherwise while the generation of VFA might cut off the contact between the biofilm cells and the electrode. From the above, these CV data confirmed the direct advantage of the ZVI on electron transfer progress while the system operated normally, compared to the control one.

(a) moderate loading phase $0.72 \mathrm{gCOD} / \mathrm{gMLSS} . \mathrm{d}$

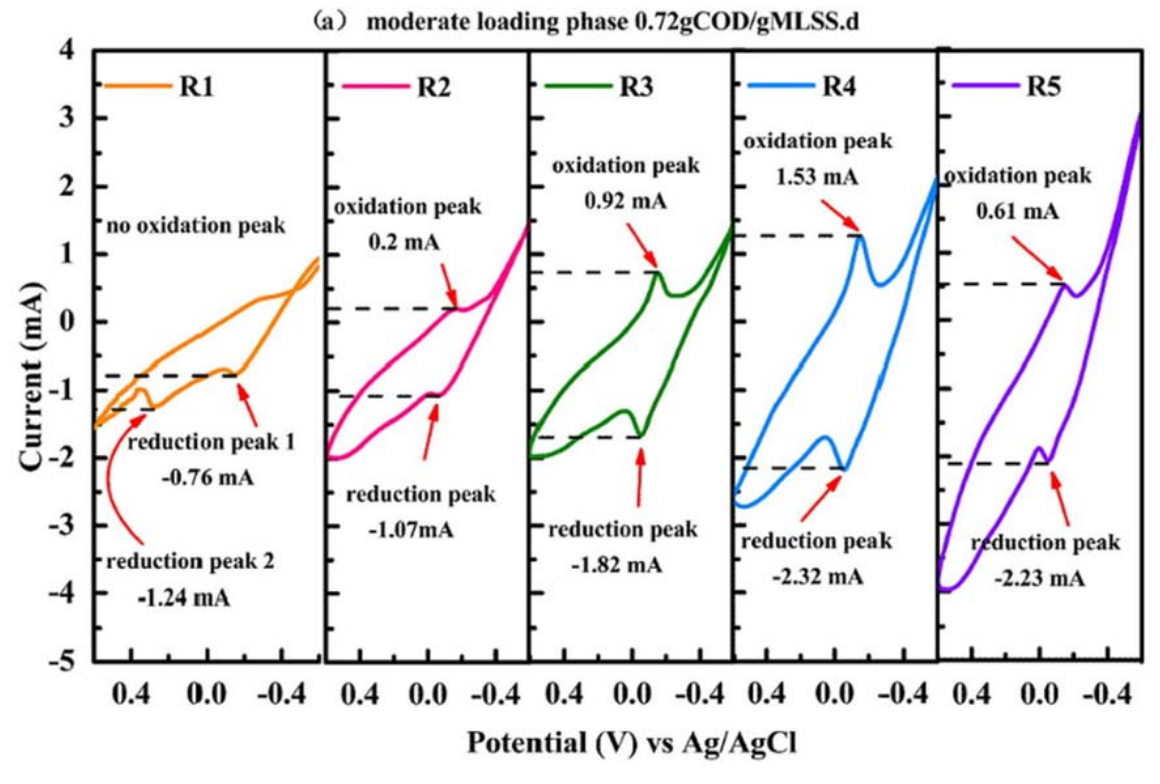




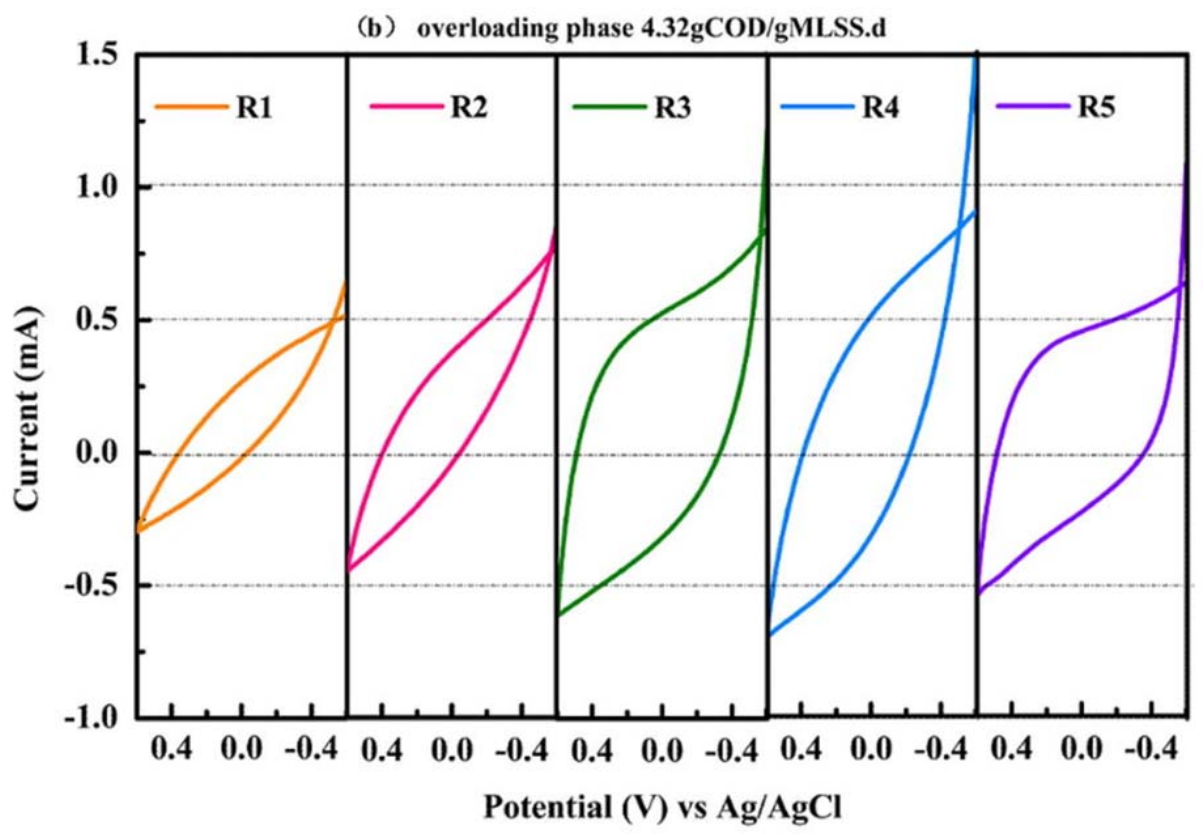

Fig. 6. Experimental cyclic voltammetry with different ZVI during (a) moderate loading phase (0.72 gCOD/gMLSS d) and (b) overloading phase (4.32 gCOD/gMLSS d).

\subsection{The mechanism of ferric iron transfer pathway released by ZVI}

The large amounts of solid iron species likely damaged the cellular structure by accumulating on the cell surfaces as ferrous precipitate or encapsulating the microbial cells. Therefore, in order to alleviate the negative impact of solid iron species on microorganisms, the amount of ZVI added should not be too large, since excessive ZVI will weaken the ZVI-facilitated outcome. Therefore, how to maximize this while minimize the microbe inhibition to the ZVI-based anaerobic biosensor is displayed below in Figs. 7 and 8.
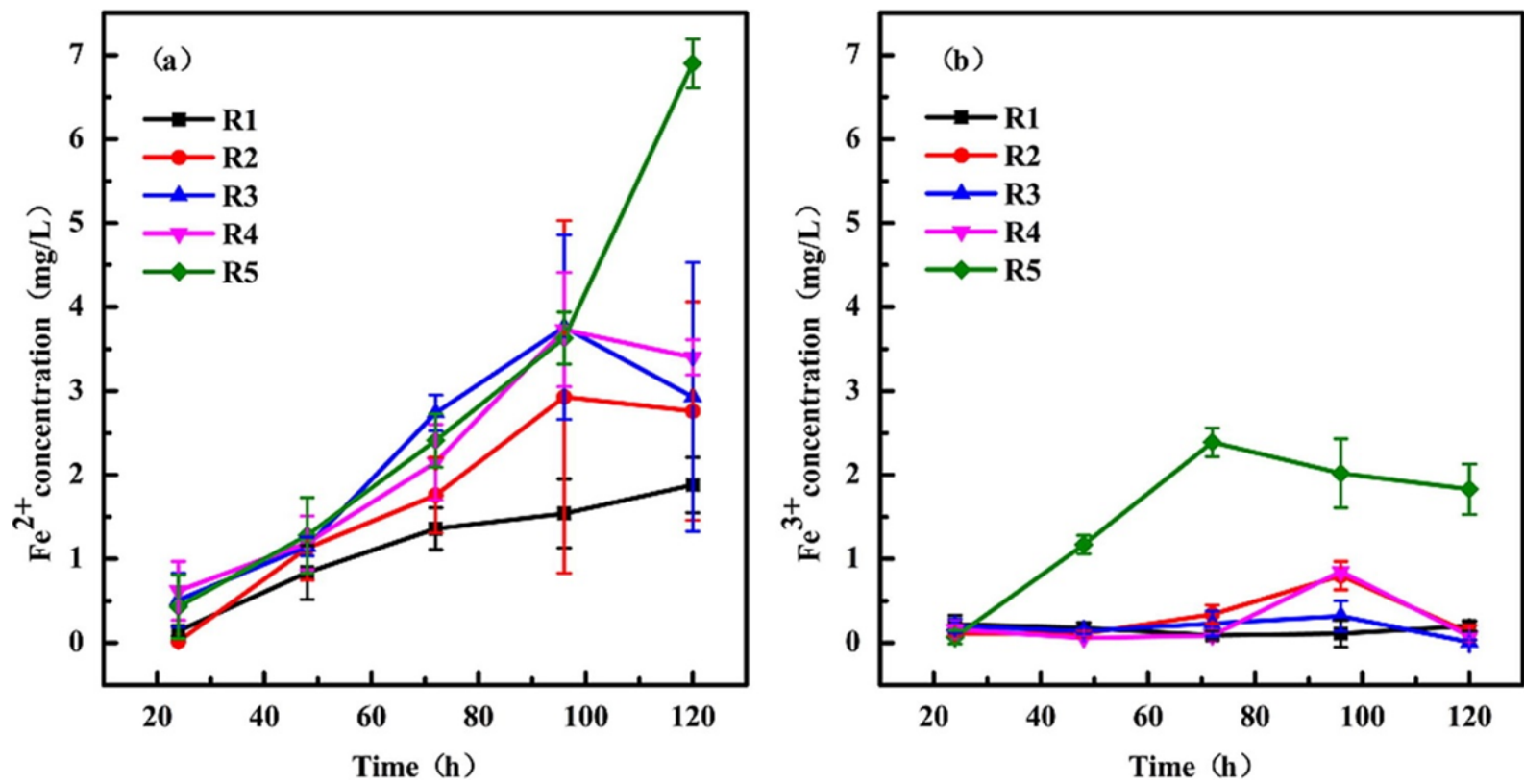

Fig. 7. The variation of $\mathrm{Fe}^{2+}$ concentration (a) and $\mathrm{Fe}^{3+}$ concentration (b) respectively in sludge with different amounts of ZVI during the integrated system's operation 

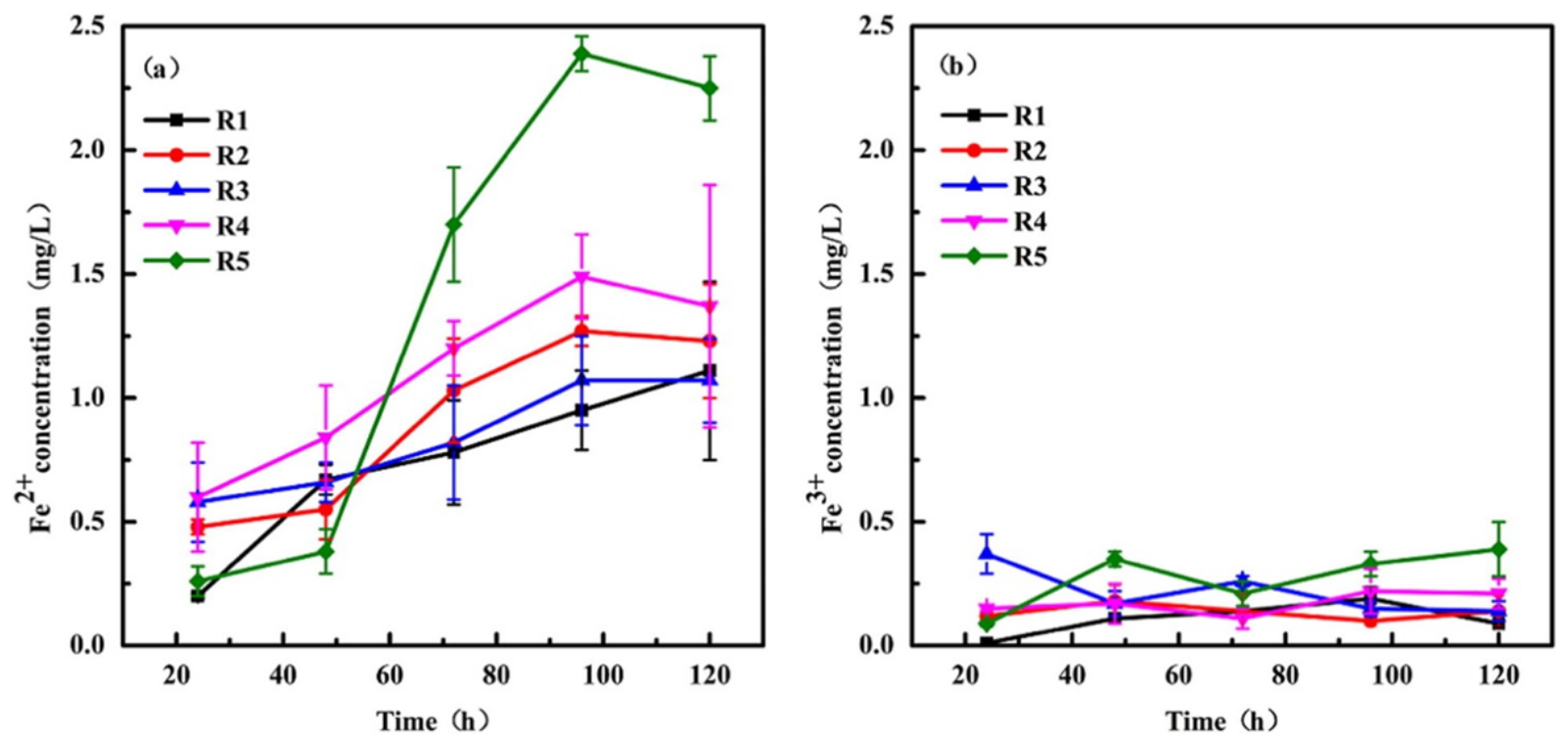

Fig. 8. The variation of $\mathrm{Fe}^{2+}$ concentration (a) and $\mathrm{Fe}^{3+}$ concentration (b) respectively in effluent with different amounts of ZVI during the integrated system's operation

As can be seen in Figs. 7 and 8, studied here were the variations in $\mathrm{Fe}^{2+}$ and $\mathrm{Fe}^{3+}$ concentration in sludge and effluent with added ZVI during the $120 \mathrm{~h}$ operation. In the early stages, $\mathrm{Fe}^{2+}$ and $\mathrm{Fe}^{3+}$ in sludge and effluent were all less than $1 \mathrm{mg} / \mathrm{L}$ and then increased with continuous operation in which ZVI accumulated in the bottom of the reactor, so that there was more $\mathrm{Fe}^{2+}$ and $\mathrm{Fe}^{3+}$ than effluent in the sludge. Moreover, when the $\mathrm{Fe}^{2+}$ was released from the ZVI process it further oxidized to $\mathrm{Fe}^{3+}$ by dissolved $\mathrm{O}_{2}$, and oxidants were generated at the same time. After operating for $120 \mathrm{~h}$, the $\mathrm{Fe}^{2+}$ and $\mathrm{Fe}^{3+}$ in sludge achieved $6.82 \mathrm{mg} / \mathrm{L}$ and $1.56 \mathrm{mg} / \mathrm{L}$, respectively, when the added ZVI concentration was $50 \mathrm{mg} / \mathrm{L}$. This was higher than the other ZVI dosages. Due to excessive ferric ions being toxic to microorganisms, there are some risks in using the system when ZVI exceeds $50 \mathrm{mg} / \mathrm{L}$. Hazards can be avoided through a rational control of the ZVI dosage and improve the performance of UASB-MFC biosensor effectively without affecting the system's operation. On the other hand, $\mathrm{Fe}^{2+}$ and $\mathrm{Fe}^{3+}$ in effluent did satisfy the emission standard, thus ensuring ZVI is effective and will not cause secondary pollution to the environment.

To quantify the degree of enhancement in the system of different ZVI concentrations, an enhancement factor (Q) was proposed based on the COD digestion rate as used by Wu et al. [12]. Taking into account of the economy of ZVI adding, q-value was used to estimate the enhancement efficiency of per unit ZVI. Q and q were calculated with Formula (4) and (5), respectively.

$$
\begin{aligned}
& Q=\frac{\mathrm{r}_{\text {ZVI-sludge }}-\mathrm{r}_{\text {sludge }}}{\mathrm{r}_{\text {sludge }}} \times 100 \\
& q=\frac{\mathrm{Q}}{\mathrm{C}_{\mathrm{ZVI}}}
\end{aligned}
$$

where $r_{Z V I-s l u d g e}$ is the COD digestion rate of each ZVI addition system, $r_{\text {sludge }}$ is the COD digestion rate for the control system, and $\mathrm{C}_{\mathrm{ZVI}}$ is the $\mathrm{ZVI}$ concentration in the combined system. 
The highest enhancement factor Q was obtained at the ZVI concentration of $30 \mathrm{mg} / \mathrm{L}$ and the highest q-value occurred at the ZVI concentration of $5 \mathrm{mg} / \mathrm{L}$ among the tested combined systems (see Table S1 in Supplementary Material). To avoid the problems posed by products that cause corrosion, adding a large amount of ZVI to the anaerobic sludge was not suitable.

\section{Conclusions}

This study evaluated the influence of zero-valent iron on the performance of UASB-MFC biosensor. Compared to the control group for the loading variation, the electrical signal response time shortened with the addition of ZVI which maximum reached $2 \mathrm{~h}$ with $30 \mathrm{mg} / \mathrm{L} \mathrm{ZVI}$ added compared to $5 \mathrm{~h}$ of control reactor during the moderate loading phase and the response time elongated with the organic loading increased. In addition, the electrical signal became amplified simultaneous when ZVI was added. This was due to ZVI-facilitated anaerobic digestion process, helped buffer $\mathrm{pH}$ in a suitable range for exoelectrogen growth and compressed electric double layer of sludge effectively as well. The measurement of volatile fatty acid revealed that the TVFA reduced and more butyric acid was converted to acetic acid by increased the activity of acetoclastic bacteria and decreased oxidation-reduction potential in the presence of ZVI during the overloading phase, while the content of propionic acid which was barely degraded. Finally, the electrochemical analysis confirmed that the lower internal resistance and higher redox activity occurred in the ZVI-biosensor, indicating that the direct interspecies electron transfer on the anode enhanced when anaerobic digestion intensified, and ZVI plays an important role in the sensing process. This research has provided ponderable manner and information that can promote the performance of biosensor and further extend its application value.

\section{Acknowledgements}

This study is financially supported by the National Natural Science Foundation of China - China (Nos. 51578375, 51378349, 51638011), and Program for Innovative Research Team in University of Ministry of Education of China (Grand No. IRT-17R80).

\section{Appendix A. Supplementary material}

Supplementary data associated with this article can be found, in the online version, at http://dx.doi.org/10.1016/j.cej.2017.06.181.

\section{References}

[1] B.E. Logan, B. Hamelers, R.A. Rozendal, U. Schrorder, J. Keller, S. Freguia, P. Aelterman, W. Verstraete, K. Rabaey, Microbial fuel cells: methodology and technology, Environ. Sci. Technol. 40 (2006) 5181-5192.

[2] L. Zhuang, S.G. Zhou, Y.T. Li, T.L. Liu, D.Y. Huang, In situ Fenton-enhanced cathodic reaction for sustainable increased electricity generation in microbial fuel cells, J. Power. Sources 195 (2010) 1379-1382.

[3] H.P. Luo, G.L. Liu, R.D. Zhang, S. Jin, Phenol degradation in microbial fuel cells, Chem. Eng. J. 147 (2009) 259-264. 
[4] H. Liu, S.A. Cheng, B.E. Logan, Production of electricity from acetate or butyrate using a singlechamber microbial fuel cell, Environ. Sci. Technol. 39 (2005) 658-662.

[5] P. Aelterman, K. Rabaey, H.T. Pham, N. Boon, W. Verstraete, Continuous electricity generation at high voltages and currents using stacked microbial fuel cells, Environ. Sci. Technol. 40 (2006) 3388-3394.

[6] S.-E. Oh, B.E. Logan, Voltage reversal during microbial fuel cell stack operation, J. Power. Sources 167 (2007) 11-17.

[7] B.H. Kim, I.S. Chang, G.C. Gil, H.S. Park, H.J. Kim, Novel BOD (biological oxygen demand) sensor using mediator-less microbial fuel cell, Biotechnol. Lett. 25 (2003) 541-545.

[8] Y.F. Zhang, I. Angelidaki, A simple and rapid method for monitoring dissolved oxygen in water with a submersible microbial fuel cell (SBMFC), Biosens. Bioelectron. 38 (2012) 189-194.

[9] Y. Jiang, P. Liang, C.Y. Zhang, Y.H. Bian, X.F. Yang, X. Huang, P.R. Girguis, Enhancing the response of microbial fuel cell based toxicity sensors to $\mathrm{Cu}(\mathrm{II})$ with the applying of flow-through electrodes and controlled anode potentials, Bioresour. Technol. 190 (2015) 367-372.

[10] A. Kaur, J.R. Kim, I. Michie, R.M. Dinsdale, A.J. Guwy, G.C. Premier, Microbial fuel cell type biosensor for specific volatile fatty acids using acclimated bacterial communities, Biosens. Bioelectron. 47 (2013) 50-55.

[11] H. Jia, G. Yang, J. Wang, H.H. Ngo, W.S. Guo, H.W. Zhang, X.B. Zhang, Performance of a microbial fuel cell-based biosensor for online monitoring in an integrated system combining microbial fuel cell and upflow anaerobic sludge bed reactor, Bioresour. Technol. 218 (2016) 286-293.

[12] D.L. Wu, S.S. Zheng, A.Q. Ding, G.D. Sun, M.Q. Yang, Performance of a zero valent iron-based anaerobic system in swine wastewater treatment, J. Hazard. Mater. 286 (2015) 1-6.

[13] N. Kumar, P. Chaurand, J. Rose, L. Diels, L. Bastiaens, Synergistic effects of sulfate reducing bacteria and zero valent iron on zinc removal and stability in aquifer sediment, Chem. Eng. J. 260 (2015) 83-89.

[14] L. Daniels, N. Belay, B.S. Rajagopal, P.J. Weimer, Bacteria methanogenesis and growth from CO2 with elemental iron as the sole source of electrons, Science 237 (1987) 509-511.

[15] S. Luo, P. Qin, J. Shao, L. Peng, Q. Zeng, J.D. Gu, Synthesis of reactive nanoscale zero valent iron using rectorite supports and its application for Orange II removal, Chem. Eng. J. 223 (2013) $1-7$.

[16] H.N. Liu, G.T. Li, J.H. Qu, H.J. Liu, Degradation of azo dye Acid Orange 7 in water by $\mathrm{Fe}$ 0/granular activated carbon system in the presence of ultrasound, J. Hazard. Mater. 144 (2007) 180-186.

[17] Z.M. Jiang, L. Lv, W.M. Zhang, Q. Du, B.C. Pan, L. Yang, Q.X. Zhang, Nitrate reduction using nanosized zero-valent iron supported by polystyrene resins: role of surface functional groups, Water Res. 45 (2011) 2191-2198.

[18] P. Westerhoff, J. James, Nitrate removal in zero-valent iron packed columns, Water Res. 37 (2003) 1818-1830.

[19] A. Shimizu, M. Tokumura, K. Nakajima, Y. Kawase, Phenol removal using zerovalent iron powder in the presence of dissolved oxygen: roles of decomposition by the Fenton reaction and adsorption/precipitation, J. Hazard. Mater. 201-202 (2012) 60-67. 
[20] R. Chand, N.H. Ince, P.R. Gogate, D.H. Bremner, Phenol degradation using 20,300 and 520 kHz ultrasonic reactors with hydrogen peroxide, ozone and zero valent metals, Sep. Purif. Technol. 67 (2009) 103-109.

[21] X. Qiu, Z. Fang, X. Yan, F. Gu, F. Jiang, Emergency remediation of simulated chromium (VI)polluted river by nanoscale zero-valent iron: laboratory study and numerical simulation, Chem. Eng. J. 193-194 (2012) 358-365.

[22] X. Zhang, S. Lin, Z.L. Chen, M. Megharaj, R. Naidu, Kaolinite-supported nanoscale zero-valent iron for removal of $\mathrm{Pb} 2+$ from aqueous solution: reactivity, characterization and mechanism, Water Res. 45 (2011) 3481- 3488.

[23] J.M. Triszcz, A. Porta, F.S.G. Einschlag, Effect of operating conditions on iron corrosion rates in zero-valent iron systems for arsenic removal, Chem. Eng. J. 150 (2009) 431-439.

[24] A. Neumann, R. Kaegi, A. Voegelin, A. Hussam, A.K.M. Munir, S.J. Hug, Arsenic removal with composite iron matrix filters in Bangladesh: a field and laboratory study, Environ. Sci. Technol. 47 (2013) 4544-4554.

[25] W. Yin, J. Wu, P. Li, X. Wang, N. Zhu, P. Wu, B. Yang, Experimental study of zero-valent iron induced nitrobenzene reduction in groundwater: the effectsof $\mathrm{pH}$, iron dosage, oxygen and common dissolved anions, Chem. Eng. J. 184 (2012) 198-204.

[26] C. Gu, H.Z. Jia, H. Li, B.J. Teppen, S.A. Boyd, Synthesis of highly reactive subnano-sized zerovalent iron using smectite clay templates, Environ. Sci. Technol. 44 (2010) 4258-4263.

[27] C. Su, R.W. Puls, T.A. Krug, M.T. Watling, S.K. O’Hara, J.W. Quinn, N.E. Ruiz, A two and half-year-performance evaluation of a field test on treatment of source zone tetrachloroethene and its chlorinated daughter products using emulsified zero valent iron nanoparticles, Water Res. 46 (2012) 5071-5084.

[28] L.J. Matheson, P.G. Tratnyek, Reductive dehalogenation of chlorinated methanes by iron metal, Environ. Sci. Technol. 28 (1994) 2045-2053.

[29] J.M. Triszcz, A. Port, F.S.G. Einschlag, Effect of operating conditions on iron corrosion rates in zero-valent iron systems for arsenic removal, Chem. Eng. J. 150 (2009) 431-439.

[30] S. Shirin, V.K. Balakrishnan, Using Chemical reactivity to provide insights into environmental transformations of priority organic substances: the Fe-0-mediated reduction of acid blue 129, Environ. Sci. Technol. 45 (2011) 10369-10377.

[31] A. Vlyssides, E.M. Barampouti, S. Mai, Influence of ferrous iron on the granularity of a UASB reactor, Chem. Eng. J. 146 (2009) 49-56.

[32] J.X. Zhang, Y.B. Zhang, X. Quan, S. Chen, Effects of ferric iron on the anaerobic treatment and microbial biodiversity in a coupled microbial electrolysis cell (MEC) - anaerobic reactor, Water Res. 47 (2013) 5719-5728.

[33] K. Yetilmezsoy, F. Llhan, Z. Sapic-Zengin, S. Sakar, M.T. Gonullu, Decolorization and COD reduction of UASB pretreated poultry manure wastewater by electrocoagulation process: A posttreatment study, J. Hazard. Mater. 162 (2009) 120-132.

[34] H.F. Cheng, W.P. Xu, J.L. Liu, H.J. Wang, Y.Q. He, G. Chen, Pretreatment of wastewater from triazine manufacturing by coagulation, electrolysis, and internal microelectrolysis, J. Hazard. Mater. 146 (2007) 385-392.

[35] Y.W. Liu, Y.B. Zhang, B.J. Ni, Zero valent iron simultaneously enhances methane production and sulfate reduction in anaerobic granular sludge reactors, Water Res. 75 (2015) 292-300. 
[36] H. Liu, S.A. Cheng, L.P. Huang, B.E. Logan, Scale-up of membrane-free singlechamber microbial fuel cells, J. Power. Sources 179 (2008) 274-279.

[37] A. Vintiloiu, M. Boxriker, A. Lemmer, H. Oechsner, T. Jungbluth, E. Mathies, D. Ramhold, Effect of ethylenediaminetetraacetic acid (EDTA) on the bioavailability of trace elements during anaerobic digestion, Chem. Eng. J. 223 (2013) 436-441.

[38] A. Punal, M. Trevisan, A. Rozzi, J.M. Lema, Influence of C: N ratio on the start-up of upflow anaerobic filter reactors, Water Res. 34 (2000) 2614-2619.

[39] Standard Methods for the Examination of Water and Wastewater, 20th ed, American Public Health Association, Washington, DC, 1998.

[40] M.H. Pournaghi-Azar, B.M. Fatemi, Simultaneous determination of ferric, ferrous and total iron by extraction differential pulse polarography: application to the speciation of iron in rocks, Microchem. J. 65 (2000) 199-207.

[41] J.M. Fernandez-Sanchez, E.J. Sawvel, P.J.J. Alvarez, Effect of Fe-0 quantity on the efficiency of integrated microbial-Fe-0 treatment processes, Chemosphere 54 (2004) 823-829.

[42] D.I. Masse, R.L. Droste, Comprehensive model of anaerobic digestion of swine manure slurry in a sequencing batch reactor, Water Res. 34 (2000) 3087-3106.

[43] K. Rabaey, N. Boon, S.D. Siciliano, M. Verhaege, W. Verstraete, Biofuel cells select for microbial consortia that self-mediate electron transfer, Appl. Environ. Microbiol. 70 (2004) $5373-5382$.

[44] G.Y. Zhen, X.Q. Lu, Y.Y. Li, Y. Liu, Y.C. Zhao, Influence of zero valent scrap iron (ZVSI) supply on methane production from waste activated sludge, Chem. Eng. J. 263 (2015) 461-470.

[45] Y.H. Feng, Y.B. Zhang, X. Quan, S. Chen, Enhanced anaerobic digestion of waste activated sludge digestion by the addition of zero valent iron, Water Res. 52 (2014) 242-250.

[46] X. Kong, Y.H. Wei, S. Xu, J.G. Liu, H. Li, Y.L. Liu, S.Y. Yu, Inhibiting excessive acidification using zero-valent iron in anaerobic digestion of food waste at high organic load rates, Bioresour. Technol. 211 (2016) 65-71. 